\title{
UHIVERSITY OF CALIFOANIA
}

\section{LIYEAUDRE}

\section{WEUTROHICS OF GUB-CRTTICAL PAGT FIEGION}

BLANKRIS FOR D-T FUSION REACTORS

\author{
J. D. Lee
}

June 15, 1972

Thls mport was prepeted as an account of woak oponsored by the United Stafes Government. Neither the United Staten nor the United Statea Aromic Energy Commlation, nor any/ of their employees, nor any of tholr contractort, wubcontractors, or their imployees, mokes any wartenty i oxpress or impliod, or aseumes any logal lisbility or rauponulbility for the accuracy, completeness or unofulaess of any Information, apparatus, product ot procests disclosed, or rapresents thef lts use would not infernge privataly owned rlghts:

This paper was prepared for publication in the Iraceediogs of the Tth Interaoclaty Energy Converaion Engineoring Canfarence, Ban Diego, Califomia September 25-29, 1972

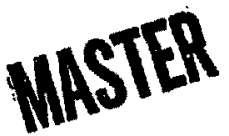


ABSTHACP

Deutronice of Bub-Criticel Fast Fission Blanketg for D-T Fusion Reactora". J. D. Lee, Lawrence If vermore Laboratory, Livermore,

$\because \quad$ Cellfornita.

The coupling of tusion and fisston has

the potential of algoiflently reducing plasma confinement eriteria below that required for a pure fugion aystem thile also reduclng rysile trel doubling t: qes below those posaible with pure Isiselon aystems.

To give a better feeling for tualonflesion'a potential, and problems, a neutronic epprated of the aub-eritical fest flesion blanket concept 1s fresented. Resulto indeate energy lincrenses over non-rlasion blenkets of a Iector of 10 to 20 (250 to $500 \mathrm{NoV}$ ger $14 \mathrm{NaV}$ ruaton neutron) are posaible in blakets where tritium breading, cocling, structure, and flesile tual breeding requirements are considered.

Work performed under the ausplees of the U.B. Atoule Energy Comilesion. 
WIILE FUSION AND FISSION are generally considered atrons competitors, they might alao be attractive partners. As presentily cancelved $D-T$ fusion reactors will be pover poor but neutron rich. Flselon breeder resctors are guat the opposite, porer rich but neutron poor. Together, fusion and figeion might be attractive, while separately they might not. The Idea of fugion-r1ugion goes back to the early 50'в but 1nterest hag been generally cool and what result are avaflable are generolly Inconclu日ive.

In 1953, Poroll proposed a $U^{2}$ s 8 blanket and speculated that "200 to $400 \mathrm{MeV}$ of firaion energy could be generated per fubion neutron" (1) a prellminary calculation that estimated energy generation of approximgtely $160 \mathrm{MeV}$ from a $\mathrm{U}^{2}$ blanket (2).

In 1960 , Weale et al, reported on exper1mental measuremente made on a $40^{\prime \prime}$ uranium metal cylindrical pile with a $14 \mathrm{MeV} D-T$ neutrop sourcs in the center. Measured $U^{2} 3$ and $U^{20}$ flasion rates were 1.18 and 0.28 per $14 \mathrm{MeV}$ neutron and the $U^{230}(n, y)$ rate was 4.08. The authorg postulated from th1s experiment that $15 \mathrm{col}$ and $30 \mathrm{~cm}$ thlok uranium blankets courd produce $150 \mathrm{MeV}$ and $220 \mathrm{MeV}$ respectively. per $14 \mathrm{MeV}$ Bource neutron (3). The first substantive neutronic analyais of a flesile blanket was reported in a 1965 theold by Lontal, in which, he found a "pract1cal and fessible blanket conteining ( $L_{1} F-B e F_{2}$ $\mathrm{UF}_{h}$ ) to give epproxdmately twice the energy of a non-flesile blonkut while producing the required tritium (4).

At the 1969 Culham Conference on tublon reactor technology, Lidsky reported on hls "F1oaion-Fusion Bymliosia" in wh1ch excess rusion Induced, neutrong are thermalized and used to breed Fisille fuel whloh in turn is uaed to increase the effective braeding ratio or a separate flasion reactor $(5)$. In a opecific eximple, a $D-T$ furion reactor with thorium in the blanket producing $0.325 \mathrm{v}^{2}$ atomi por rumion supplemented the breeding in a molten oult resetor having a breeding ratio of 0.96 . Bpecifylag a desired fiel doubling time or 5.0 gaars hidshy caloulated the required fualon to flselon ratio to be 0.585 . This ratio ofves $342 \mathrm{MaV}$ from the rission resctor per fusion reaction, whioh nakes the total enerey generation n $360 \mathrm{MoV}$ per D-T Tusion.

- aumbers in parentheses degignare Feferences at ond of paper. 
$\therefore$ There are two beste ipprosches to sub 10a-

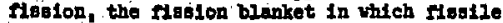
triel 1a bred and "burnad", and Hdakg".

"Grmblosis" In whieh a fertile blenket aupplowents the breeding of a seperate fleston

renctor.

While Ildat' proposal 10 gut te attractive, the aub-eritical Hadion biantet has not been analysed in vuflelent detall to determine If It 18 c credible alternative to Lidsky'.

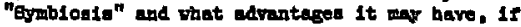
ans.

\section{BBUHOTIC APPRATBAL}

To be netironlealy vible, the aub-eritical sast flasion blanket mut ganerate large amounta

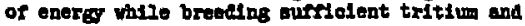
Hoatle fuel tor thal doubling tines of leag than 10 years. The blankot mist alao be suberition.

A sertes of nevtronlo enculations vero run to doterndino in a ganeral way the potential of aub-critical fast figelon blankets. Not veutronio celeulations ware perromed uning the "gors bonte cario manoport code" (6). Ite cods used 66 group noutron crogd-egettons based on the IIL Bowertom evoluated 11brary. Mont problenis used 5 batobed of 200 source neutrond (24 Nov) each.

The folloring are consldered:

(1) Bnergo goneration per 14 Mar rualon noutron,

(2) Tritium Breeding.

(3) Fiosion produets affect.

(4) The offect afferont types or

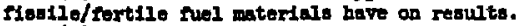

(5) Limits inpeged by erititualty eafety.

(6) Fsoion tuel doubling timen.

(7) Heat tranafer and structural requirenexta.

The rirat atep vas to conalder 2 arge (errectivelg infinite) areemblies of pure thortum, uranium 238 and natural uranilus. The reaulting enera generation and Nagtlo nel broeding reeotions per $14 \mathrm{MoV}$ nautron woro:

Blanket Yater1al Bnerg(Nov) Breeding fiesctions

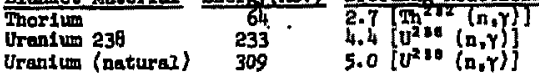

J. D. Lee

It appeara the potential is here as predicted.

It 10 aleo intereating to compare the above calculated results for uranium (netural) with Heale' $B$ experimontal measurementa on the $40^{n}$ 
urantur metal cylindrial pile (3):

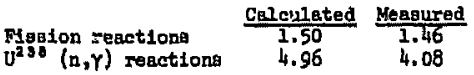

The ogreement It good olnce the calculationel model is effectively on Inflnite asembly.

Now let's considex vhat bappeng when tritlum breeding, cooling, and structure are conoldered by examining a conceptuel blarket design containing uranium, nloulvm, and 11thinm Blarket geometry is a two zone apberlcel shell with an Inner radius or 200 crl and a outer radiue of $300 \mathrm{~cm}$. The makeup of the blamket goned are:

\begin{tabular}{|c|c|c|}
\hline$\frac{\text { Zone } 1}{30 \text { eni }}$ & $\frac{\text { Elewont }}{\text { II }}$ & 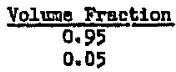 \\
\hline$\frac{\text { Zone } 2}{\text { Tro (n) }}$ & $\begin{array}{l}\mathrm{U} \\
\mathrm{LA} \\
\mathrm{Bb}\end{array}$ & $\begin{array}{l}0.65 \\
0.30 \\
0.05\end{array}$ \\
\hline
\end{tabular}

$A$ number of afferent depleted it and $U$ leotoplo ratios (but with blanket geonstry and material volume fractions hald constant? were tried to maximlee ene'zy generation ville ot1ll breading the required tritium. Doar optimum repults yare found for il depleted to $4 \pi$ is (T.56\% 1i naturaI) and $U$ deploted to $0.04 \%$

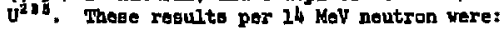

$$
\begin{aligned}
& \text { Buergor Generation - } 103 \mathrm{MeV} \\
& \text { Tritium Breoding } \quad-0.986 \\
& \mathrm{U}^{23 \mathrm{~B}}(\mathrm{a}, \mathrm{y}) \text { Reactions }-1.68
\end{aligned}
$$

Thege reauita are interesting, and with 1.68 $\mathrm{Pu}^{23}$ breeding reactions per D-T fusion it is obvilous $\mathrm{Pu}^{23}$ ghaurd replace the $\mathrm{U}^{215}$ ag the risolle tuel. A ceries of problems were run using the agm bianket makeup to setermine the erfect of $\mathrm{Pu}^{219}$ soncentration. Resulta are 11sted an rable 1, cases 1-4.

The results indicate a rast flssion blanket could be an excellent breoder. The 4 , Pu (case 4) has a Pu breeding ratio of 3.1 whlle generating $430 \mathrm{MeV}$. (Pu breeding sat1o J. D, Lee is the $U^{29}(n, y)$ reactions per $\operatorname{Pu}^{29}(n, f)$ reactiong.) Wote that fagt fiesion of $u^{23}$ accounts for a large percentage of the fiagion reactiona: 41 for the $4 \%$ Ph case. 
CRITICALITY - As the PU looding is Inereased the blanket energy generation Increases because the ansembly's neutron multiplication $(\mathrm{K})$ increases. Since we want the blanket asgembly to be aubcritical at all times, I vill specify $X \max$ to be 0.90. Al liated in Table 1 energy generation and $K$ for the $4 \%$ Pu case vas $430 \mathrm{NeV}$ and 0.843 respectively and for the 5\% Fu cese it vas 930 MeV and 0.934 . The $K$ csiculations were performed using the "Tart" Honte Carlo Codo (T). To est1mate energy Beneration for this blanket $H$ th a $K$ of 0.9 I vill agaume:

$$
\text { Bhergy }=c * \frac{1}{1-K}
$$

The 4\% and 5\% cesse gives values for the conotant $C$ of 67.6 and 61.3 reopectively. So a simllar blanket wth $K=0.9$ ahould nave an eneres generation between

$E_{\text {indn }}=61.3 \cdot \frac{1.0}{1.0-0.9}=613 \mathrm{MeV}$ and

$\mathrm{E}_{\operatorname{mex}}=67.6 \cdot \frac{1.0}{1.0-0.9}=676 \mathrm{NoV}$

Therefore an energy multiplication oi $=30$ times over D-T rugion with non-fierion blankets appears posalble in aub-eritical flsoton blankete vith $\mathbb{Z} \leq 0.9$. FISGION PRODUCIS - The cares dfocussed thiz far have neglected Hision products. To gee wist offect Higion product bufldup has on blanket performance, I reran the $4 \% \mathrm{Pu}$ case with B\% Flagion products (FP). This agaunes Individual tuel elements are remored with Bs burnup (n $80,000 \mathrm{MHD} / \mathrm{T}$ ). While this burnup is high by today' $a$ atandarda it is below the upper deal $\mathrm{gm}$ target of $100,000 \mathrm{MWD} / \mathrm{T}$ for Hagton breders (8). The results are llated in the last rou of Table 1. (cage 6). The results are encouraging the breeding ratio $(3.0)$ decreased c $77 y$ 3\% and the fraotion or $\mathrm{v}^{2} \mathrm{~d}$ Ilasion $(0.44)$ increased $5 \%$. There vas also a 29x decrease in energy generation but this can be offset by alightiy increapIng the Pu loading.

PU'1 DOUBLING TIMIE - To be attract1 ve, blankets consuming $\mathrm{Pu}^{20}$ muat hare a Pils doubling time 10:日 than the electrle porror demand doubling time. Bectrical porer requirementa are doubling approximately overy elght years so I vil aseume a five year niol doubing timo is necessary to replace old plante as well an moeting the new power demaind. UBJ.pg the reJ. D. Lee sults from the $45 \mathrm{Pu}+85$;P case (16) discusiged nbote the average blanket power density ( $P_{\text {ave }}$ ) 
required to gtve a 5 year Ph doubling time

(ta) 18 :

$$
P_{\text {ave }}=5.08 \times 10^{-21} \cdot \frac{\mathrm{E} \cdot \mathrm{U}(\mathrm{Pu})}{t_{\mathrm{d}} \cdot[\mathrm{U}(\mathrm{n,Y})-\mathrm{Pu}(\mathrm{n}, \mathrm{f})]}
$$

where: $P_{\text {ave }} \equiv$ average power density (H/cc)

$$
\begin{aligned}
& \mathrm{I}^{\text {ave }} \equiv \text { energs generation }\left(\frac{\mathrm{HeV}}{\mathrm{fu} \text { ion }}\right) \\
& \mathbf{N}(\mathrm{Pu}) \equiv \mathrm{Fu} \text { atom denalty }\left(\frac{\text { atomu }}{\mathrm{cc}}\right) \text {. } \\
& \mathrm{t}_{\mathrm{d}} \equiv \mathrm{Pu} \text { doubling tion (year) } \\
& {[U(n, \gamma)-P u(n, f)] \equiv \text { Pu breeding excess }\left(\frac{\text { ationg }}{\text { rubion }}\right)} \\
& P_{\text {ave }}=5.08 \times 10^{-21} \cdot \frac{306}{5} \cdot \frac{1.20 \times 10^{21}}{1.66} \\
& =225 \mathrm{H} / \mathrm{cc}
\end{aligned}
$$

The wail loading (WL), flux of $14 \mathrm{MaV}$ rusion neutrons on the Irst vall, vseoniated with this avernge nower in:

$$
\begin{aligned}
\mathrm{HL} & =\mathrm{P}_{\mathrm{ave}} \cdot \mathrm{Tb} \cdot \frac{14}{2} \\
& =225 \cdot 70 \cdot \frac{14}{306}=725 \mathrm{H} / \mathrm{cm}^{2}=7.25 \mathrm{MH} / \mathrm{M}^{2}
\end{aligned}
$$

Where To a thickness of blanket urabium zone. Both the power dengity. (225 $\mathrm{J} / \mathrm{cc}$ ) and vall loading (7.25 MN/M $\mathrm{M}^{2}$ ) needed to get a flve jear doubling time in this example blanket should not pase an undue heat irinsfer problem and are therefore encouraging. Neutron heating of the flrst wall is not the only heating mechantsm, photon ard lona must also be cnnaldered, therefore each type of plasms containment w11l Impoge somewhat different wall loading 11mitations, THORIUN FUEL - BInce thortum 18 also a fertile element, the risolie $\mathrm{U}^{23}$ Iaotope is the decay

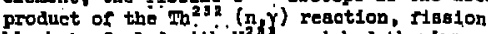
blankets fueled with $U^{2}$ enriched thorlun are aleo a posalbility.

To compare thortum to wranium a fes problens vere sun in whiah the urantum 238 and plutonium vere replac $d$ by thorium and wrandum 233. All other blanket paramotera were unchanged Including the presence of $8 \%$ fission produota, Resuite are liated in Mable 2. Inrolun is clenrly infertor to urantum for this type of blanket. The breeding ratio is only 1.3 J. D. Lee compand to 3.0 and a fraction of th flasion in only 0.07 compared rith 0.44 for $U^{230}$. The 
average blanket pover requlred for a flve year doubling time 1B:

$$
\begin{aligned}
P_{\text {sro }} & =5.08 \times 10^{21}: \frac{478}{5} \cdot \frac{1.49 \times 10^{21}}{.69} \\
& =1049 \mathrm{~W} / \mathrm{ce}
\end{aligned}
$$

compared with $225 \mathrm{~W} / \mathrm{cc}$ for the uranium case. Mrus OXIDE Furs - The naxt ster taken in this neutronic appraiteal of the oub-critical fast Hssion blenket concept was to look at the erfect of chenglng to a mixed oxide fuel. While the metal tuol should be neutronicerly ouperior the oxide afpitars to be the popular cholce for the 1lquld metal fast breeder Nogion reactorg predently being doveloped. Bo It Is of Intereat to see how oxd de fuel performs in ribaion blankete.

As in the thorium case, I will atart by replacing the $U$ + Pu metal tuel by the mired oxlde. All caser have BS riselon products approximating an average burn-up of 48 of Initial heavy metal loading ( $U$ + Pu). As in the previaus cases the bialc blanket conslats of a $30 \mathrm{~cm}$ 1sner zone containing 958 by volume (r/o) Ifth1um coolent and 5 v/0 njoblum gtructure and a $70 \mathrm{~cm}$ outer zone contalning the utxed oxide ruel. In all cases the lithium 10 depleted in $\mathrm{LL}$. contalining $48 \mathrm{LI}_{1}$ ingtead of the natural $7.56 \%$.

Boven milied oxdde cales were run to get an Ides of how Pu enrlehment, atructural valume fraction, coolant volume firaction, and In the last case how a decrease in zone $i$ thlekness tran 30 to $15 \mathrm{~cm}$ erfects the performance. Table 3 gives Zone 2's Pu enrichment and material volume Iractions for esch blanket oage wbile rable 4 listg tho resulta.

As expected, the oxdic is inferior to the metal. Comparing the oxido case 12 to its metal counterpart the breeding ratio has dropped trom 3.0 to 1.6 and the $U^{2}$ fo fletion fraction has dropped from 0.44 to 0.26 .

$A$ better comparison is douhling time. The average power density required for the case if oxide, compared with $225 \mathrm{~K} / \mathrm{ce}$ for 1 ts metal counterpurt to have a five year doubling time 18:

$$
\begin{aligned}
P_{\text {Bve }} & =5.08 \times 10^{-21} \cdot \frac{483}{5} \cdot \frac{1.30 \times 10^{21}}{1.06} \\
& =602 \mathrm{H} / \mathrm{cc}
\end{aligned}
$$$$
\text { J. D. Lee }
$$

This does not mean the oxdde is unecceptable, It only mears that from a doubling time atand- 
point it is not as good as a metal gysters.

Table 5 liots, for each oxide case, the average power density regulred to give a five year Pu doubjing time.

The nverage yower deng1ty for cages 5-7 are most likely tho high, therefore their doubling titine must increege. Doubling time and pover density are laveraely proportloned.

\section{CONCLUSIONB}

The coupling be tusion and rission appeare to be a plausible concept. In this atuany an enerby 1ncrease of a factor of 10 to 20 (250 to $500 \mathrm{MeV}$ per $14 \mathrm{MeV}$ neutron) over non-rission blankets vas achieved in sub-critical fast Flasion blankota whese tritium breeding requirements vere met and uhich in most cases vere capable of having a flve year flosile fuel doubling time.

Heat trangfer and structural requirements vill bave a profound effect on blanket neutronlcs. Higher power dengity and risalle breeding ratios can lover flogile fuel doubling times. But blgher power dengitieg will increase coolant and structural fractione which in turn lovers breeding ratio. Obviously optimization 1a required to minimize doubling time for esch ruel type.

Metal and oxide fuels are I1kely canaldates but aarbldes and nitrides should also be conBldered because of thels higher thermal conductivity and fuel denglties, compared to the oxdde.

other questions auch as criticality osfety under accldent conditions and economies or fusion-fission gyatems must alno be deatt with.

Thers appears to be no clear cut neutronic advantage of the aub-critical rast risajon blanket over a ferilie blanket supplementing the breeding of a beparate flasion reuctor. While using fugion neutrons to Induce fast riseion in $\mathrm{V}^{2}$ is advantageoug and the $\mathrm{Fu}$ is bred and burned ingitu, the advantages wight be out-welghed by the problems or cooling and fueling a high power fiosion blanket inalde the bigh $\mathrm{\theta}$ magnets required to contein the D-T plagma. Aleo, ahort duration shut down of the fubion seactor rould not Interrupt pourer production of a aeparata critical Hegion reactor.

There are tro mijor advilatages to the rusion flasion hybrid. F1rBt, it could supplement the tuel production of risgion breeders In the event the breeding in cominerefally' attractive pure Nission breedora 18 not surficlent to meet the demand for now generating 
capacity. And second, the greatly 1ncreased energy genoration per D-T fubion of the hybrid syatem (10 to 20 times that of a D-T rusion only system) sigalficantly reduces plasira contsinmed requirements for a viable pover ayotem. This abould afd fusion research by provlaing an intermediate goal. The ultimate goal is of course an all riblon pover econour.

\section{FBPLFEACAB}

1. P. Powell, "Proposal for a Driven Thermonuolear Reaction Cover". Letter CHLD to Flaherty, ABC, Repoit Lis-24920 (Revleed), Oetober 6, 1953 .

2. D. H. Imholf et $\boldsymbol{n}$, "A Driven Thermonuclear Fover Breeder", Callfornla Researeh Corporetion, Report Cil-6, June 1, 1954. 3. J. W. Wealo et if, "Hadeurements or the Reaction Rate Diatribution Producad by a Bource of 14 HeV Heutrons at the Centor of a Uranium Jotel P110". UiK. Atomio Nespone Resoarch Estublishment, J. Nuwlear Bnorg A/B, 14, 91, 2961.

4. 4. H. Lontid, "8tudy of thermopuclear Reactor Blankot v1 th Fisalbie Iuclider", NIT Technical Report, 436, July 6, 1965.

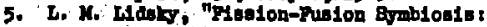
Generel Conelderations and a 8pectelo Erompla", NTP, Proceeding of the Nuclear Fusion Reactors Conferrence, Culhap, Ingland, peger 41-53, Beptember 1969;

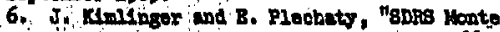
Carlo Heutron-Iranuport code for the cDC-6600",

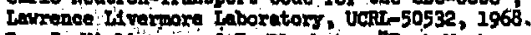
7. J. Ximlinger and B. Plechaty. Mrart Wonte Carlo Meutron' Traneport Code". Ievrience LAveriore Laboratory, UCIR-',2e, 197. B. Tut Breader Resctor H pont, BdSoon Buetric Institute, Rub. No, 68-28, paso 49, 1968.

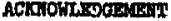

Ho thanks to B1xl Cough in the ARC CTR offlce for collectiog and diesentrating sowe or the early reforivaded on rusion-t1iston. 
Table 1 - Urandim and Plutondun Metal Blanket Results (Per 14 MeV Neutron)

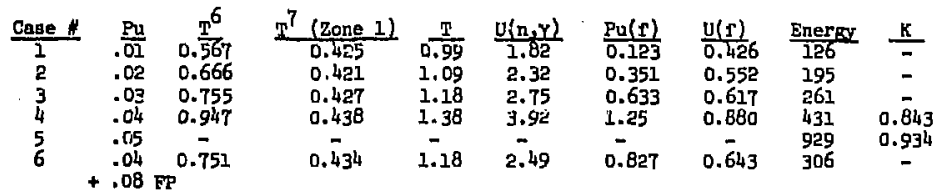

where:

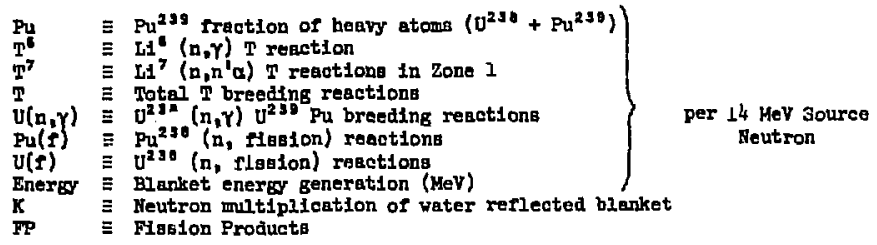

J. D. Lee

see p. 4 
Table 2 - Thorfin Blaniset Rearlts

\begin{tabular}{|c|c|c|c|c|c|c|}
\hline$y^{233}$ & $n^{7}$ (zone i) & $T(\operatorname{tota})$ & $\operatorname{Tn}(n, r)$ & $\underline{u}(r)$ & $\operatorname{Tn}(r)$ & Bnersor \\
\hline $\begin{array}{l}0.515 \\
0.868\end{array}$ & $\begin{array}{l}0.417 \\
0.422\end{array}$ & $\begin{array}{l}0.93 \\
1.29\end{array}$ & $\begin{array}{l}1.61 \\
3.00\end{array}$ & $\begin{array}{l}0.719 \\
2.31\end{array}$ & $\begin{array}{l}0.106 \\
0.38\end{array}$ & $\begin{array}{l}17 E \\
478\end{array}$ \\
\hline
\end{tabular}


Table 3 - Mlxed OxIde Blanket (Zone 2) Pu Inrichment and Material Volume Fractions Hired Oxide

\begin{tabular}{|c|c|c|c|c|}
\hline $\begin{array}{l}\text { Cans } \\
1 \\
2 \\
3 \\
4 \\
5 \\
6 \\
7\end{array}$ & $\begin{array}{l}\text { Pu } \\
.08 \\
.09 \\
.09 \\
.09 \\
.11 \\
.11 \\
.11\end{array}$ & $\begin{array}{l}\frac{\text { Fuel }}{.65} \\
.65 \\
.60 \\
.50 \\
.50 \\
.50 \\
.50\end{array}$ & $\begin{array}{l}\text { L1 Coolent } \\
.30 \\
.30 \\
.30 \\
.40 \\
.40 \\
.30 \\
.30\end{array}$ & $\begin{array}{c}\text { Mb Strueture } \\
.05 \\
.05 \\
.10 \\
.10 \\
.10 \\
.20 \\
.20\end{array}$ \\
\hline
\end{tabular}

- zone 1 thickness reduced from 30 to $15 \mathrm{~cm}$.

Tablo 4 - Mixed Oxdde Blanket Besulte

\begin{tabular}{|c|c|c|c|c|c|c|c|c|}
\hline Caue : & $m^{6}$ & $I^{7}$ (2one 1) & $\mathrm{T}$ (total) & $\underline{u}(n, \gamma)$ & Pu(r) & $u(t)$ & Energor & $\mathbf{K}$ \\
\hline $\begin{array}{l}1 \\
2 \\
3 \\
4 \\
5 \\
6 \\
7\end{array}$ & $\begin{array}{l}0.825 \\
1.062 \\
0.828 \\
0.828 \\
1.13 \\
0.851 \\
0.891\end{array}$ & $\begin{array}{l}0.435 \\
0.436 \\
0.436 \\
0.428 \\
0.441 \\
0.421 . \\
0.252\end{array}$ & $\begin{array}{l}1.26 \\
1.50 \\
1.26 \\
1.26 \\
1.57 \\
1.27 \\
1.14\end{array}$ & $\begin{array}{l}2.02 \\
2.82 \\
1.80 \\
1.41 \\
1.72 \\
1.50 \\
2.63\end{array}$ & $\begin{array}{l}1.09 \\
1.76 \\
1.13 \\
0.843 \\
1.54 \\
1.21 \\
2.06\end{array}$ & $\begin{array}{l}0.44 \\
0.62 \\
0.38 \\
0.31 \\
0.112 \\
0.30 \\
0.50\end{array}$ & $\begin{array}{l}316 \\
483 \\
313 \\
243 \\
400 \\
313 \\
521\end{array}$ & $\begin{array}{l}0.835 \\
= \\
= \\
= \\
=\end{array}$ \\
\hline
\end{tabular}

J. D. Lee

ses p. 7 
Table 5 - Averoge Porrer Densities Eequired for a Pu Doubling The of Five Years in Mired Oxide Blankets

\begin{tabular}{cc} 
Cage & Pave (W/ec) \\
\hline 1 & 400 \\
2 & 602 \\
3 & 570 \\
4 & 433 \\
5 & 2777 \\
6 & 1349 \\
7 & 1142
\end{tabular}

J. D. Lee

gee p. B 